\title{
Surgical techniques for the treatment of rectal endometriosis: a systematic review of randomized controlled trials and observational studies
}

\author{
Pedro POPOUTCHI ${ }^{1}$, Oswaldo Wiliam MARQUES JUNIOR ${ }^{1,2}$, Pedro AVERBACH ${ }^{3}$, \\ Celso Augusto Milani CARDOSO FILHO' ${ }^{1,2}$ and Marcelo AVERBACH ${ }^{1}$
}

Received: 11 February 2021 Accepted: 18 June 2021

\begin{abstract}
Background - Endometriosis is a common disease in reproductive-age women and it is estimated to occur in up to $50 \%$ of those with infertility. Intestinal involvement is reported in up to a third of the cases. This condition is related to chronic pain and loss of quality of life, resulting in emotional, social and economic costs. Treatment consists of hormonal block and surgical resection, with variable side effects and efficacy. The best choice for surgical treatment for rectal endometriosis is a matter of discussion regarding the indication and the best technique to be employed. Objective - To summarize data on indications, results and complications of surgical techniques for the treatment of rectal endometriosis. Methods - This comprehensive systematic review is a compilation of the available literature and discussion, carried out by a team with experience in the surgical treatment of intestinal endometriosis. Data regarding indications, results and complications of conservative and radical techniques for the surgical treatment of rectal endometriosis was carefully reviewed. Searches of PubMed, EMBASE, and CENTRAL up to May 2021 were performed to identify randomized controlled trials (RCTs) and observational studies that compared at least two of the three surgical techniques of interest (i.e., shaving, discoid resection, segmental resection). Results - One RCT and nine case series studies with a total of 3,327 patients met the eligibility criteria. Participants ages ranged from a mean of 30.0 to 37.9 years old. Mean follow-up ranged from 1.2 to 42.76 months. With regards the methodological quality, overall the included studies presented a low risk of bias in the majority of the domains. Surgical treatment of rectal endometriosis is indicated for patients with obstructive symptoms and those with pain scores above 7/10. Patients with disease involving beyond muscularis propria of the rectum, documented in magnetic resonance imaging or transvaginal pelvic ultrasound with intestinal preparation, are candidates for discoid or segmental resection. The presence of multifocal disease, extension greater than $3 \mathrm{~cm}$ and infiltration greater than $50 \%$ of the loop circumference favor the radical technique. The distance from the lesion to the anal verge, age, symptoms and reproductive desire are other factors that influence the choice of the technique to be employed. The risk of complications and unfavorable functional results seems to be directly related to the complexity of the procedure. Conclusion - The choice of surgical technique performed for the treatment of rectal endometriosis is a matter of discussion and depends not only on the preoperative staging, but also on the patient's expectations, risks and potential complications, recurrence rates and the expertise of the multidisciplinary team.
\end{abstract}

Keywords - Treatment; rectal; endometriosis.

\section{INTRODUCTION}

Deep endometriosis is defined by the presence of endometrial implants located more than $5 \mathrm{~mm}$ below the peritoneal surface. It may cause changes in pelvic anatomy and can invade the uterosacral ligaments, the vagina, the bladder, the ureters and various segments of the intestines. FIGURE 1 shows a nodule causing angulation of the rectum wall. Intestinal endometriosis is characterized whenever the muscularis propria on the involved loop is compromised, and its prevalence is estimated at 3 to $37 \%$ of all endometriosis cases. The intestinal segments most often affected are the rectum and the sigmoid colon, by up to $90 \%{ }^{(1)}$. FIGURE 2 shows surgical resection specimens of infiltrative rectal endometriosis. The disease progresses slowly and has a heterogeneous clinical presentation that is often neglected, characterized mainly by pelvic pain, gastrointestinal symptoms, and infertility. These symptoms may be severe enough to significantly impact their quality of life and cause physical disabilities ${ }^{(2)}$.

Although clinical treatment of endometriosis can reduce the size of the lesions and the intensity of the symptoms, the response is incomplete and recurrence after treatment discontinuation is high, with a failure rate around $40 \% \%^{(3-6)}$. Additionally, hormonal treatment for endometriosis is associated with erratic bleeding, increased weight, reduced libido, and headaches ${ }^{(7)}$. Another important aspect to consider is that patients may not adhere to the clinical treatment due to a reproductive desire. Thus, surgical treatment of intestinal endometriosis is an efficient option for symptomatic female patients ${ }^{(8)}$. Various studies have shown that surgical resection

Declared conflict of interest of all authors: non

Disclosure of funding: no funding received

${ }^{1}$ Hospital Sírio-Libanês, Instituto de Ensino e Pesquisa, São Paulo, SP, Brasil. ${ }^{2}$ Fundação Antônio Prudente - A.C.Camargo Hospital, São Paulo, SP, Brasil. ${ }^{3}$ Disciplina de Coloproctologia, Departamento de Gastroenterologia da Faculdade de Medicina da Universidade de São Paulo, São Paulo, SP, Brasil.

Corresponding author: Pedro Popoutchi. E-mail: pedropopoutchi@gmail.com 


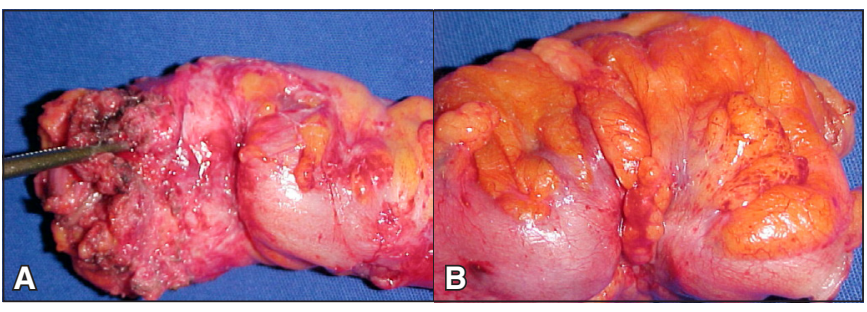

FIGURE 1, A and B - Nodule causing rectal angulation.

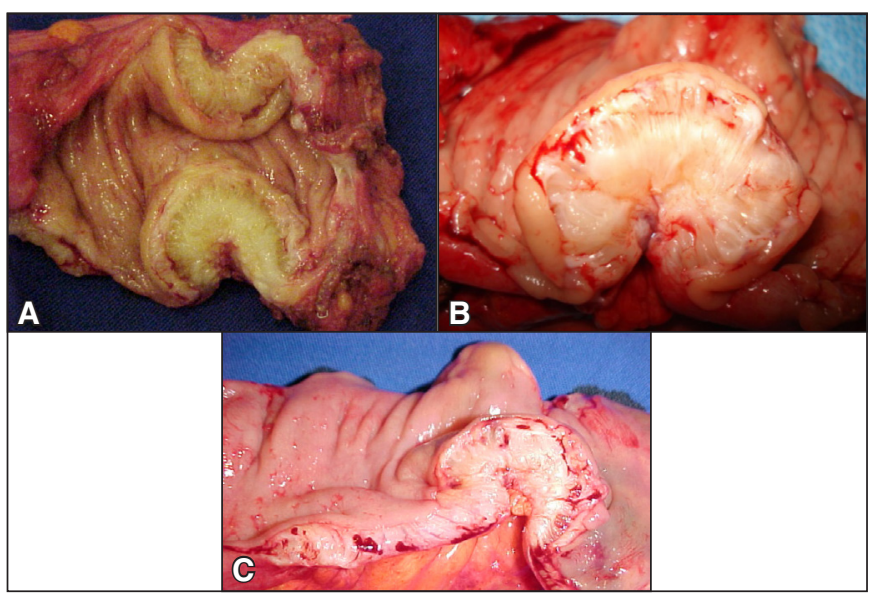

FIGURE 2. A, B, and C - Infiltrating endometriosis extrinsic to the rectal wall.

of all lesions, including those in the intestines, is linked to lower recurrence, significant improvement of gastrointestinal symptoms, improvement in quality of life, and satisfactory results in gestation rates $^{(9-11)}$. Therefore, surgical treatment should be recommended to women who accept the risks and would rather avoid a prolonged clinical treatment, as well as those for whom hormonal treatment has failed or who present contraindications to hormonal treatment, and those at risk of urinary or intestinal obstruction.

The surgical approach to rectal endometriosis is subject to discussion when it comes to indication and the best technique to be applied. The preoperative staging of the disease through clinical exam, transvaginal ultrasound with bowel preparation, magnetic resonance imaging, and rectal ecoendoscopy, when available, presents sensitivity and specificity above $90 \%$ and is important in defining the best therapeutic strategy. Support by a multi-disciplinary team is essential to the success of the treatment ${ }^{(12-14)}$. Implementing an algorithm for the surgical team that is based on supplementary examinations is associated with higher rates of full resection of the disease, more conservative surgeries, and lower incidence of complications $^{(15)}$.

The most important information for surgical planning are: size and number of lesions, depth of intestinal wall infiltration, rate of rectal circumferential involvement, and distance from the anal verge. These elements are required for the definition of the surgical technique, which must be individualized and discussed with each patient, taking into account three important parameters: symptom control, recurrence rate, and desire to reproduce ${ }^{(14,15)}$.

Laparoscopy is an effective and safe method for accessing the abdominal cavity in high volume centers ${ }^{(16,17)}$. Robotic surgery has been used in Brazil since 2010 to treat intestinal endometriosis ${ }^{(18)}$. However, studies still show similar results, at a higher $\operatorname{cost}^{(19,20)}$. We therefore conducted an updated systematic review of all randomized controlled trials (RCTs) and observational studies that assessed the effects of different surgical techniques (i.e., shaving, discoid resection, segmental resection) in patients with rectal endometriosis.

\section{METHODS}

The Cochrane Handbook of Systematic Reviews of Interventions $^{(21)}$ guided our choice of methods. Our reporting adheres to the Preferred Reporting Items for Systematic Reviews and MetaAnalyses (PRISMA) Statement ${ }^{(22)}$.

\section{Eligibility criteria}

The inclusion criteria were:

- Study design: all RCTs and observational studies (i.e., case series, case-control, and cohort studies) that compared at least two of the three surgical techniques of interest (i.e., shaving, discoid resection, segmental resection).

- Patients: adults with rectal endometriosis.

- Interventions: surgical techniques (i.e., shaving, discoid resection, segmental resection).

- Comparisons: we compared the surgical techniques against each other.

- The patient-important outcomes that we were interested in were: mortality; recurrence; surgical major complications (e.g., pelvic abscess, rectal vaginal fistulae, dehiscence) and minor complications (e.g., stenosis of colorectal anastomoses, transitory bladder atony); fertility.

\section{Data source and searches}

No restrictions were placed on language, year of publication or publication status. We searched Cochrane Central Register of Controlled Trials (CENTRAL, issue 5, 2021), US National Library of Medicine (PubMed, from 1966 to 2021), and Excerpta Medica Database (EMBASE, from 1980 to 2021). Search terms describing rectal endometriosis and surgical techniques were combined (Appendix TABLE 1). The last date was May 5th, 2021.

\section{Searching other resources}

In addition to an electronic database search, we made a manual search in the reference lists of every study deemed eligible in order to identify additional trials that were later included; all potentially eligible studies were screened in duplicate.

\section{Selection of studies}

Pairs of reviewers independently screened all titles and abstracts identified by the search through the Covidence online software. Full-text articles for potentially eligible studies were obtained and screened independently by reviewer pairs using the same eligibility criteria as with title and abstract screening. Consensus for stages of screening, data extraction, and risk of bias assessments were established by discussion and adjudication by a third reviewer, as necessary.

\section{Data extraction and risk of bias assessment}

Once a final set of eligible studies were identified, reviewer pairs independently extracted data for the following variables from each study using a pre-standardized data extraction form with: characteristics of the study design; participants; description of interventions; and duration of follow-up. 
TABLE 1. Characteristics of included studies related to setting, study design, number of participants, mean age, gender, eligibility criteria, criteria used and follow-up.

\begin{tabular}{|c|c|c|c|c|c|c|c|c|c|c|}
\hline $\begin{array}{l}\text { Author, } \\
\text { year }\end{array}$ & Country & $\begin{array}{l}\text { Multicentre or } \\
\text { single-centre }\end{array}$ & Scenario & $\begin{array}{l}\text { \# of participants } \\
\text { in the whole } \\
\text { sample }\end{array}$ & Inclusion criteria & Exclusion criteria & $\begin{array}{l}\text { Surgical } \\
\text { technique }\end{array}$ & $\begin{array}{l}\text { Age, mean } \\
\text { (SD), y }\end{array}$ & $\begin{array}{l}\text { \% Male whole } \\
\text { sample }\end{array}$ & $\begin{array}{l}\text { Mean (SD), } \\
\text { follow-up } \\
\text { (months) }\end{array}$ \\
\hline \multicolumn{11}{|c|}{ Case series studies } \\
\hline \multirow{3}{*}{ Abo, 2018} & \multirow{3}{*}{ France } & \multirow{3}{*}{ Single-centre } & \multirow{3}{*}{$\begin{array}{l}\text { Department of Obstetrics and Gynecology at Rouen } \\
\text { University Hospital, Rouen, France }\end{array}$} & \multirow{3}{*}{364} & \multirow{3}{*}{$\begin{array}{l}\text { Patients with deep endometriosis infiltrating the rectosigmoid had a } \\
\text { laparososcopic surgical procedure to treat bowel endometriosis. }\end{array}$} & \multirow{3}{*}{$\begin{array}{l}\text { Both rectal disc excision and segmental resection } \\
\text { of the sigmoid colon. }\end{array}$} & Shaving & $36.1(7.1)$ & \multirow{3}{*}{ NA } & \multirow{3}{*}{$40(22)$} \\
\hline & & & & & & & Discoid & $30.0(4.7)$ & & \\
\hline & & & & & & & Segmental & $31.4(5.2)$ & & \\
\hline \multirow{3}{*}{$\begin{array}{l}\text { Abrão, } \\
2019\end{array}$} & \multirow{3}{*}{ Brazil } & \multirow{3}{*}{ Single-centre } & \multirow{3}{*}{ Hospital Beneficencia Portuguesa of Sao Paulo } & \multirow{3}{*}{172} & \multirow{3}{*}{$\begin{array}{l}\text { Women with significant pain (visual analog scale }>7 \text { ) who were } \\
\text { diagnosed with bowel endometriosis from preoperative imaging and } \\
\text { underwent laparoscopic surgery for bowwel endometriosis at a large } \\
\text { referral center between } 2014 \text { and } 2017 \text {. }\end{array}$} & \multirow{3}{*}{$\begin{array}{l}\text { Any previous bowel surgery, pregnant or } \\
\text { menopoausal, diagnosed with infammmatory bowel } \\
\text { disease, or had a current or previous malignancy. }\end{array}$} & Shaving & $37.9(4.8)$ & \multirow{3}{*}{ NA } & \multirow{3}{*}{1.2} \\
\hline & & & & & & & Discoid & $36.1(5.6)$ & & \\
\hline & & & & & & & Segmental & $36.7(5.0)$ & & \\
\hline \multirow{2}{*}{$\begin{array}{l}\text { Ballester, } \\
2016\end{array}$} & \multirow{2}{*}{ France } & \multirow{2}{*}{ Multicentre } & \multirow{2}{*}{$\begin{array}{l}\text { Tenon University Hospital and Rouen University } \\
\text { Hospital }\end{array}$} & \multirow[t]{2}{*}{60} & \multirow{2}{*}{$\begin{array}{l}\text { Women who underwent complete surgical removal of colorectal } \\
\text { endometriosis and required postoperative ICSI-IVF. }\end{array}$} & \multirow{2}{*}{ NR } & $\begin{array}{l}\text { Shaving or } \\
\text { discoid }\end{array}$ & NR & \multirow{2}{*}{ NA } & \multirow{2}{*}{ NR } \\
\hline & & & & & & & Segmental & NR & & \\
\hline \multirow{2}{*}{$\begin{array}{l}\text { Fanfani, } \\
2010\end{array}$} & \multirow[b]{2}{*}{ Italy } & & 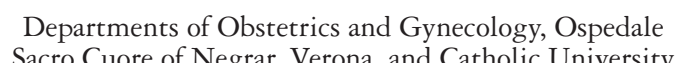 & & DIE with rectosigmoid involvement, nodules with maximum diameter & & Discoid & $33^{\circ}$ & & \\
\hline & & Single-centre & $\begin{array}{l}\text { Sacro Cuore of Negrar, Verona, and Catholic University } \\
\text { of the Sacred Heart, Rome, Italy }\end{array}$ & 136 & $\begin{array}{c}\leq 3 \mathrm{~cm} \text { with bowel stenosis } \leq 60 \% \text {, and presence of endometriosis-related } \\
\text { symptoms. }\end{array}$ & NR & Segmental & $32^{\circ}$ & NA & 33 \\
\hline & & & & & Endometriosis of the recto-sigma and eventual other intestinal. & Patients with DIE which not affected the & Segmental & $36.3(5.6)$ & & \\
\hline $\begin{array}{l}\text { Gutérrez, } \\
2019\end{array}$ & Spain & Single-centre & $\begin{array}{l}\begin{array}{l}\text { Department of Gynaecology of "La Paz" University } \\
\text { Hospital }\end{array} \\
\text {. }\end{array}$ & 143 & $\begin{array}{l}\text { localization (ileum, cecum, appendix) with histological confirmation; } \\
\text { correct posibility and disposition to follow-up }\end{array}$ & $\begin{array}{l}\text { bowel, previous bowel resection, no monitoring } \\
\text { possible. }\end{array}$ & Discoid & $34.9(6.8)$ & $\mathrm{NA}$ & $42.76(1.3)$ \\
\hline & & & & & & & Shaving & $36.6(5.8)$ & & \\
\hline Hudelist, & & & & & Women underwent surgical treatment for DIE out of which all showed & Women under the age of 18 years, patients with & Segmental & $34.5(7.0)$ & NA & 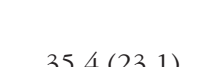 \\
\hline 2018 & Austria & Single-centre & Department of Gynecology, Hospital St. John of God & 134 & $\begin{array}{l}\text { involvement of the rectum and/or sigmoid colon involving at leass the } \\
\text { serosal and muscular layer confirmed by histological analysis. }\end{array}$ & $\begin{array}{l}\text { psychiatric disorders or a history of malignancy } \\
\text { as well as virgins. }\end{array}$ & Discoid & $34.0(0.7)$ & $\mathrm{NA}$ & 35.4(23.1) \\
\hline Millochau, & & & & & $\begin{array}{l}\text { Deep endometriosis of the low or midrectum along with concomitant } \\
\text { infiltration of the sigmoid colon or rectosigmoid junction, at least } 5\end{array}$ & Patients managed for multifocal colorectal & Discoid & NR & & \\
\hline 2017 & France & Single-centre & $\begin{array}{l}\text { University Hospital, Rouen, France } \\
\text { Und }\end{array}$ & 21 & $\begin{array}{l}\mathrm{cm} \text { of healthy bowel between nodules, and separate surgical procedures } \\
\text { requiring bowel sutures to be performed on multiple colorectal nodules } \\
\text { with preservation of a healthy normal vascularized bowel. }\end{array}$ & $\begin{array}{l}\text { endometriosis by two surgical procedures } \\
\text { including at least one bowwl shaving. }\end{array}$ & Segmental & NR & $\mathrm{NA}$ & $30(25.4)$ \\
\hline & & & & & & & & NR & & \\
\hline $\begin{array}{l}\text { Roman, } \\
2017\end{array}$ & France & Multicentre & 56 public and private healthcare facilities in France & 1135 & $\begin{array}{l}\text { Patients with DIE involving muscularis, submucosa or mucosa, } \\
\text { operated of from January } 1 \mathrm{st} \mathrm{to} \mathrm{December} 31 \mathrm{ss} 2015 \text {. }\end{array}$ & $\begin{array}{l}\text { Patients presenting with only superficial } \\
\text { involvement of bowel serosa. }\end{array}$ & Discoid & NR & NA & NR \\
\hline & & & & & & & Segmental & NR & & \\
\hline & & & & & All patients with deep endometriosis infiltrating the muscular laver & & Shaving & NR & & \\
\hline $\begin{array}{l}\text { Roman, } \\
2020\end{array}$ & France & Multicentre & Rouen and the Endometriosis Center, Clinique Tivoli- & 1102 & or deeper of the rectum and sigmoid colon, who had benefitted from & NR & Discoid & NR & NA & 4 to $124^{s}$ \\
\hline & & & & & 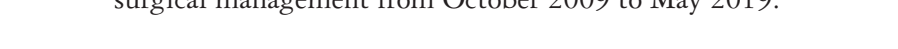 & & Segmental & NR & & \\
\hline 年 & (t) & & & & & & & & & \\
\hline $\begin{array}{l}\text { Roman, } \\
2019\end{array}$ & France & Multicentre & $\begin{array}{l}\text { Rouen University Hospital, Tenon University Hospital } \\
\text { and Lille Univeristy Hospital }\end{array}$ & 60 & 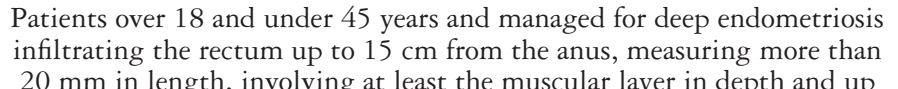 & NR & $\begin{array}{l}\text { Shaving or } \\
\text { discoid }\end{array}$ & $31^{\star}\left(27-36^{\S}\right)$ & NA & $729^{4}\left(726-743^{8}\right)$ \\
\hline & & & & & $\begin{array}{l}20 \mathrm{~mm} \text { in length, inviring at least the muscular ay } \\
\text { to } 50 \% \text { of rectal circumference. }\end{array}$ & & Segmental & $28^{4}\left(27-36^{8}\right)$ & & $727^{\circ}\left(722-736^{8}\right)$ \\
\hline
\end{tabular}

DIE: deep inflitrating endomertiosis; ICSI: intra-cytoplasmic sperm injection; IVF: in virto fertilization; NR: nor reported; NA: not applicable

APPENDIX TABLE 1. Search strategy.

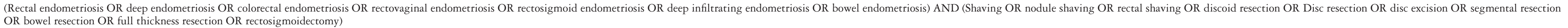


For RCTs, reviewers independently assessed risk of bias by using a modified version of the Cochrane Collaboration's tool. The tool includes nine domains: adequacy of sequence generation, allocation sequence concealment, blinding of participants and caregivers, blinding of data collectors, blinding for outcome assessment, blinding of data analysts, incomplete outcome data, selective outcome reporting, and the presence of other potential sources of bias not accounted for in the previously cited domains ${ }^{(23,24)}$.

For cohort and case-control studies, we planned to assess risk of bias with a modified version of the Ottawa-Newcastle instrument ${ }^{(25)}$ that includes confidence in assessment of exposure and outcome; however, there was no included study classified as either cohort or case-control study.

For case series, we used the single tool from the Joanna Briggs Institute (JBI) critical appraisal checklist ${ }^{(26)}$. However, in our view, the structure of the response options in both AXIS and JBI instruments leaves much to be desired. Therefore, we modified the response options to "definitely yes" (low risk of bias), "partially yes" (not all information needed available), "unclear" (no information to judge), and "definitely no" (high risk of bias), and applied it to our form for risk of bias in case series studies.

\section{RESULTS}

\section{Study selection}

Our initial searches identified 898 citations through database searches. After we removed duplicates from different databases, we retained 821 potentially relevant articles for further assessment. Based on title and abstract screening, we obtained full-paper copies for 78 citations that were potentially eligible for inclusion in the review (FIGURE 3). We excluded 64 studies for the following reasons reviews, case reports, off-topic, letter to the editor, diagnostic studies,

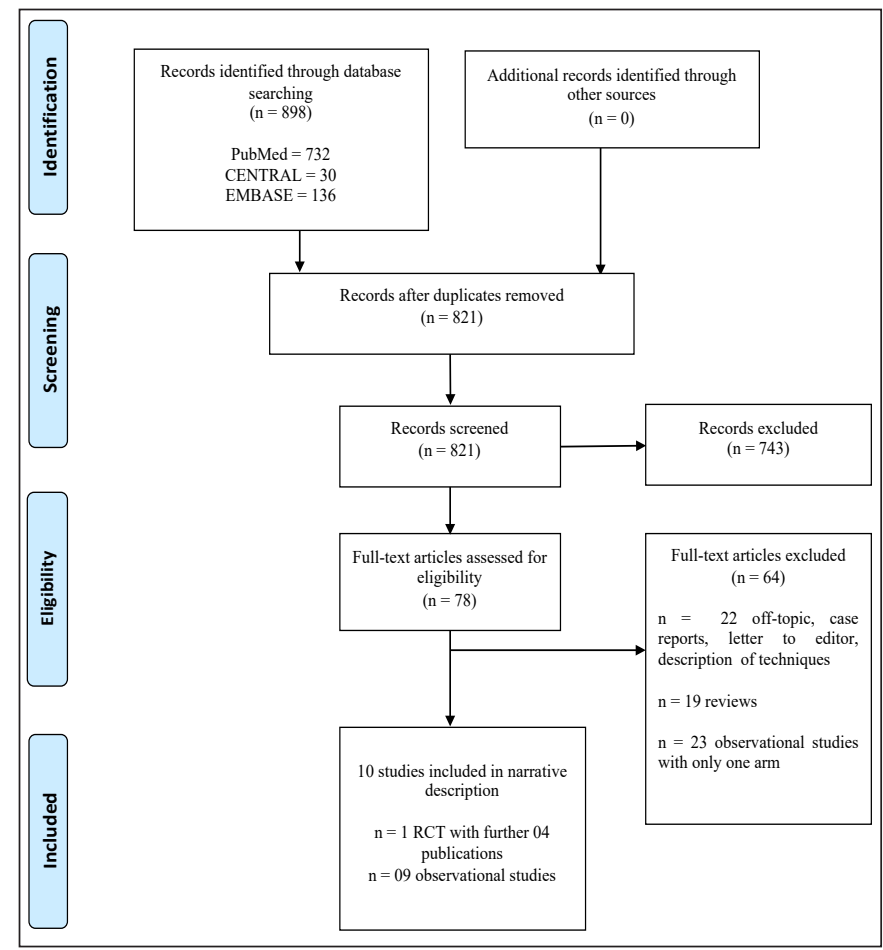

FIGURE 3. PRISMA flowchart. and observational studies with only a single arm. The remaining one $\mathrm{RCT}^{(27)}$ with further four publications and nine observational studies ${ }^{(15,28-35)}$ with a total of 3,327 patients met the minimum requirements and were included in this review. The reasons for exclusion are listed in the PRISMA flow diagram (FIGURE 3).

\section{Study characteristics}

TABLE 1 describes study characteristics related to setting, study design, number of participants, mean age, gender, eligibility criteria, criteria used and follow-up. Nine studies (90\%) were conducted largely in Europe ${ }^{(27-35)}$ and only one (10\%) in South America (Brazil) $^{(15)}$. Four studies $(40 \%)$ out of ten were multicenter ${ }^{(27,29,34,35)}$.

The RCT and case series studies sample size ranged from $21^{(33)}$ to 1,135 patients ${ }^{(35)}$. Participants ages ranged from a mean of $30.0^{(28)}$ to $37.9^{(15)}$ years old (TABLE 1).

Six studies ${ }^{(15,28,29,31,34,35)}(60 \%)$ compared all three techniques amongst them (i.e., shaving, discoid, and segmental). Mean followup ranged from $1.2^{(15)}$ to 42.76 months $^{(31)}$.

\section{Risk of bias}

FIGURE 4, TABLE 2 (Appendix) and TABLE 3 describe the risk of bias assessment. In the RCT study (FIGURE 4, panel A), only two domains blinding of participants and blinding of

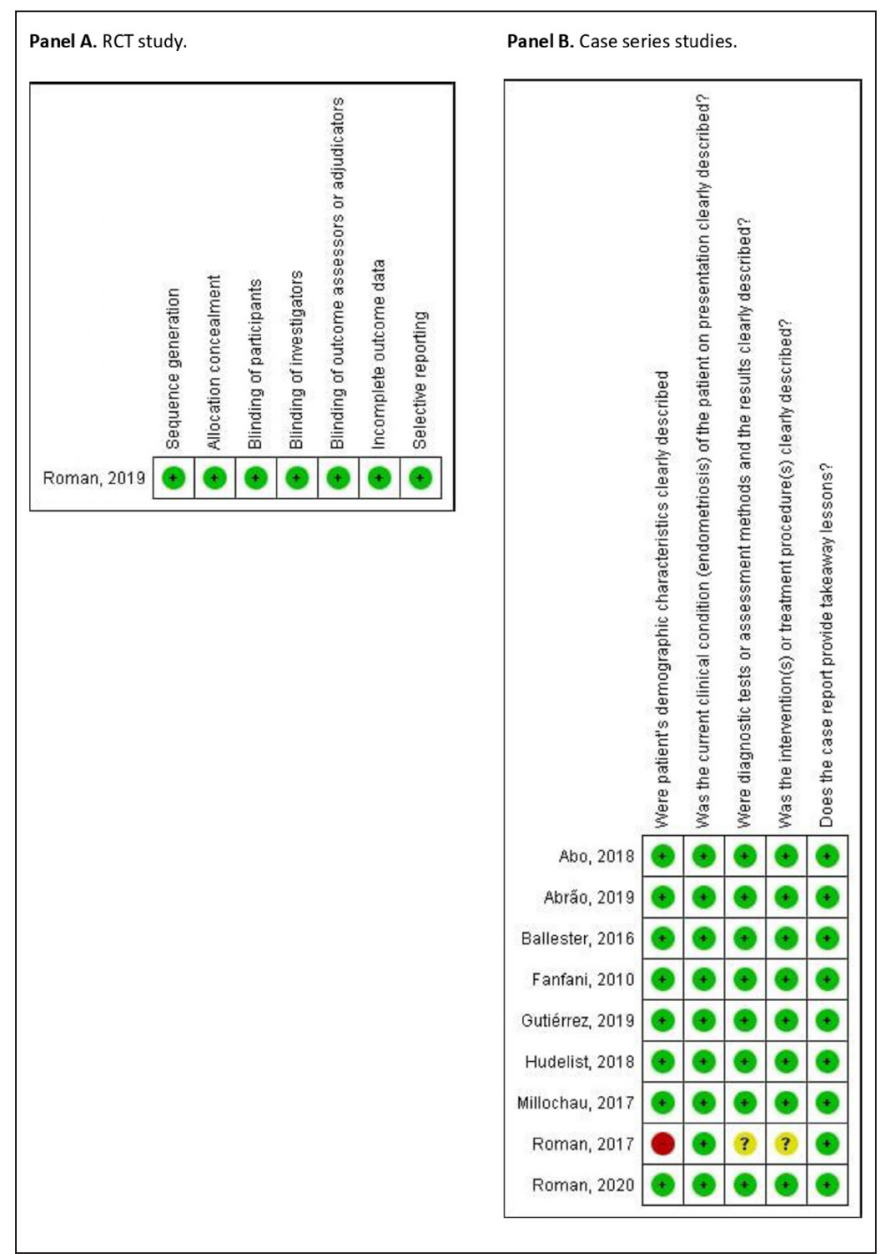

FIGURE 4. Risk of bias assessment. Panel A: RCT study. Panel B: case series studies. 
TABLE 2. Comparative analysis of surgical techniques for rectal endometriosis considering various variables.

\begin{tabular}{lccc}
\hline & Superficial resection (shaving) & Discoid resection & Segmental resection \\
\hline Technical complexity & + & ++ & ++ \\
Cost & + & ++ & ++ \\
Hospitalization period & + & ++ & ++ \\
Complications & +++ & ++ & ++ \\
Improvement in pain and quality of life indices & + & ++ & +++ \\
Risk of unfavorable functional results & +++ & ++ \\
Recurrence & & ++ \\
\hline
\end{tabular}

Appendix TABLE 2. Risk of bias for randomized controlled study.

\begin{tabular}{|c|c|c|c|c|c|c|c|c|}
\hline $\begin{array}{l}\text { Autor, } \\
\text { year }\end{array}$ & $\begin{array}{l}\text { Sequence } \\
\text { generation }\end{array}$ & $\begin{array}{l}\text { Allocation } \\
\text { concealment }\end{array}$ & $\begin{array}{l}\text { Blinding of } \\
\text { participants }\end{array}$ & $\begin{array}{l}\text { Blinding of } \\
\text { investigators }\end{array}$ & $\begin{array}{l}\text { Blinding of } \\
\text { outcome assessors } \\
\text { or adjudicators }\end{array}$ & $\begin{array}{l}\text { Incomplete } \\
\text { outcome data }\end{array}$ & $\begin{array}{l}\text { Selective } \\
\text { reporting }\end{array}$ & $\begin{array}{l}\text { Conflict of } \\
\text { interest }\end{array}$ \\
\hline $\begin{array}{l}\text { Roman, } \\
2019\end{array}$ & $\begin{array}{l}\text { Definitely } \\
\text { low risk }\end{array}$ & $\begin{array}{l}\text { Definitely low } \\
\text { risk }\end{array}$ & $\begin{array}{c}\text { Probably low } \\
\text { risk }\end{array}$ & $\begin{array}{c}\text { Probably low } \\
\text { risk }\end{array}$ & $\begin{array}{l}\text { Definitely low } \\
\text { risk }\end{array}$ & $\begin{array}{l}\text { Definitely low } \\
\text { risk }\end{array}$ & $\begin{array}{l}\text { Definitely } \\
\text { low risk }\end{array}$ & $\begin{array}{l}\text { Declared } \\
\text { and no }\end{array}$ \\
\hline
\end{tabular}

Definitely yes: low risk of bias; partially yes: probably low risk of bias; partially no: probably high risk of bias; definitely no: high risk of bias

TABLE 3. Risk of bias for case series studies.

\begin{tabular}{|c|c|c|c|c|c|}
\hline Author, year & $\begin{array}{l}\text { Were patient's } \\
\text { demographic } \\
\text { characteristics } \\
\text { clearly described? }\end{array}$ & $\begin{array}{l}\text { Was the current } \\
\text { clinical condition } \\
\text { (endometriosis) of the } \\
\text { patient on presentation } \\
\text { clearly described? }\end{array}$ & $\begin{array}{l}\text { Were diagnostic } \\
\text { tests or assessment } \\
\text { methods and the } \\
\text { results clearly } \\
\text { described? }\end{array}$ & $\begin{array}{c}\text { Was the } \\
\text { intervention(s) } \\
\text { or treatment } \\
\text { procedure(s) } \\
\text { clearly described? }\end{array}$ & $\begin{array}{l}\text { Does the case } \\
\text { report provide } \\
\text { takeaway lessons? }\end{array}$ \\
\hline Abo, 2018 & Definitely yes & Partially yes & Definitely yes & Definitely yes & Definitely yes \\
\hline Abrão, 2019 & Definitely yes & Partially yes & Definitely yes & Definitely yes & Definitely yes \\
\hline Ballester, 2016 & Definitely yes & Definitely yes & Definitely yes & Definitely yes & Definitely yes \\
\hline Gutiérrez, 2019 & Definitely yes & Definitely yes & Definitely yes & Definitely yes & Definitely yes \\
\hline Hudelist, 2018 & Partially yes & Definitely yes & Definitely yes & Definitely yes & Definitely yes \\
\hline Millochau, 2017 & Definitely yes & Partially yes & Definitely yes & Definitely yes & Definitely yes \\
\hline Roman, 2017 & Definitely no & Definitely yes & Unclear & Unclear & Partially yes \\
\hline Roman, 2020 & Definitely yes & Definitely yes & Definitely yes & Definitely yes & Definitely yes \\
\hline
\end{tabular}

Definitely yes: low risk of bias; partially yes: probably low risk of bias; partially no: probably high risk of bias; definitely no: high risk of bias; unclear: not enought information for a judgment.

investigators were rated as "probably low risk of bias". In the case series studies (FIGURE 4, panel B), one domain (i.e., demographic characteristics clearly described) was rated as "high risk of bias" in one study ${ }^{(34)}$, and two domains (i.e., results and procedures clearly described) were rated as "unclear" also at the same study ${ }^{(34)}$. Overall, the included studies presented a low risk of bias in the majority of the domains.

\section{DISCUSSION}

\section{Surgical techniques for rectal endometriosis}

Resection techniques can be classified as conservative and radical. Conservative techniques are those in which the endometriotic nodule is resected, saving the organ and most of the adjacent healthy tissue. Examples of these approaches are the discoid resection, with excision of the full thickness of the anterior wall of the rectum, and the superficial resection, when the rectal lumen is not opened. The so-called radical options include rectal segmental resections with primary anastomosis. The choice of technique depends on the characteristics of the lesion, as shown in FIGURE 5, and must be discussed with the patient and the multi-disciplinary team.

\section{Superficial resection (shaving)}

Superficial resections can be done safely by experienced laparoscopic surgeons. First described in 1991, the use of this technique is becoming more common, as it is technically easier and presents a lower rate of complications; it is reserved to patients with superficial infiltration $^{(36,37)}$. A recent study shows that shaving is indicated in infiltrations up to $5.2 \mathrm{~mm}$ in depth ${ }^{(38)}$. Patient should undergo bowel preparation in the day before the procedure, due to the possibility of opening the rectal lumen during the surgery.

With the patient under general anesthesia in the Lloyde-Davies position, a $12 \mathrm{~mm}$ incision is made on the umbilical scar in order to insert the laparoscope. Two other incisions, of $5 \mathrm{~mm}$, are normally used in the iliac fossa, and a third $5 \mathrm{~mm}$ incision on the right flank may help in dissecting the nodule. A uterine manipulator and a rectal probe allow for the individual manipulation of these 


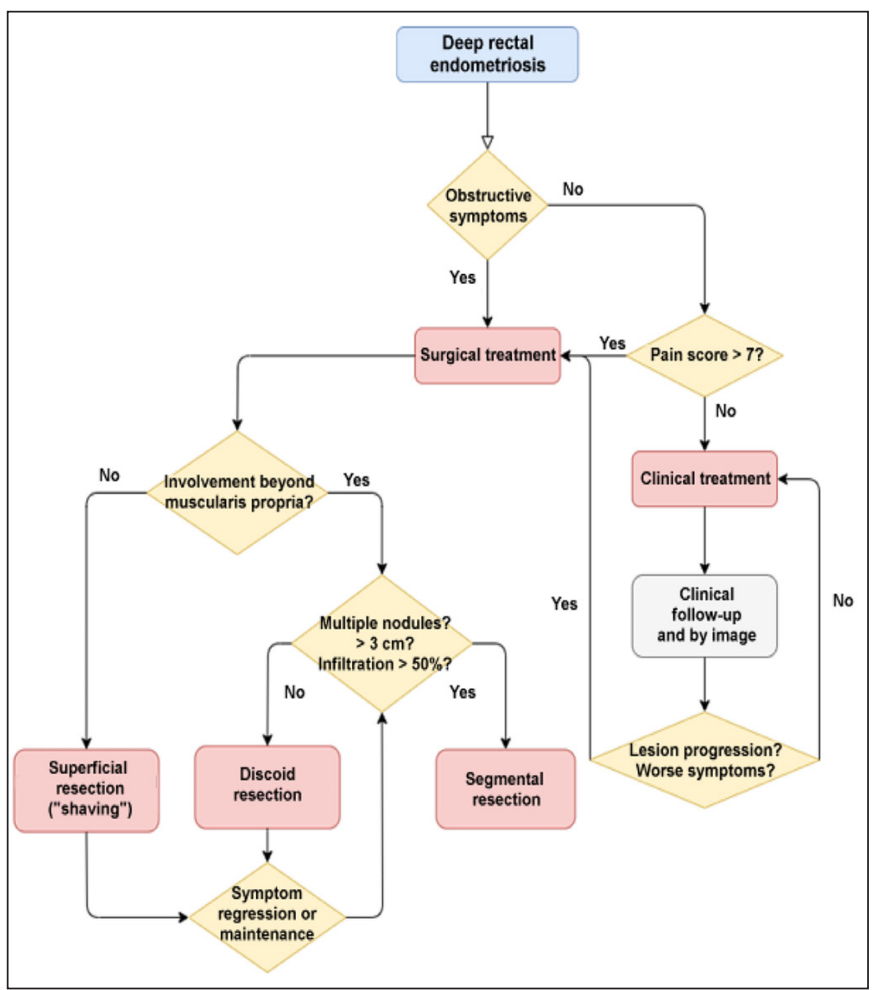

FIGURE 5. Flow diagram for therapeutic choice in rectal endometriosis.

structures. The procedure begins by dissecting the nodule from adjacent tissue and leaving it on the anterior wall of the rectum. The pararectal spaces are opened medially to the utero-sacral ligaments and next to the intestinal wall, in order to avoid hypogastric nerve lesion ${ }^{(39)}$. The lesion is then suspended and dissected, using cold, monopolar or bipolar instruments, blunt or sharp, at the junction of the white fibrous tissue with the normal tissue. In this manner, the superficial lesions involving the serous layer and/or the external muscular layer can be easily removed from the normal intestinal wall. Monopolar electric current must be used with care, since a thermal bowel injury may result in a fistula in the postoperative period. $\mathrm{CO} 2$ laser is a viable energy alternative for the superficial resection of rectal endometriosis ${ }^{(40)}$.

In cases involving larger lesions, it may be necessary to separate the ureters in order to protect them. When the disease presents with extensive involvement of the retrocervical region and the anterior rectal wall, the lesion can be divided in order to leave one part on the anterior rectal wall and the other on the retrocervical region, allowing for the separate treatment of each region. The resection of deeper lesions may result in the opening of the intestinal lumen; in such cases, the defect may be corrected with sutures in one or two layers ${ }^{(41)}$.

A prospective study by Donnez et al. with 500 patients with rectovaginal endometriosis and treated by superficial resection showed low complication rates and an $84 \%$ pregnancy rate after an average follow-up period of 3 years (from 2 to 6 years). Recurrence was significantly lower in patients who became pregnant naturally (3.6\%) in comparison with those who underwent in-vitro fertilization $(15 \%)(P<0.05)^{(42)}$. Roman et al., reported an improvement in gastrointestinal complaints, low complication rates (two patients with fistulas), and 4\% relapse, in a group of 122 superficial resec- tion patients ${ }^{(43)}$. The recurrence rates reported by Roman et al. and Gutiérrez et al. for patients who underwent superficial resection were $8.7 \%$ and $12.7 \%$, with follow-up periods of 60 and 39 months, respectively ${ }^{(31,44)}$.

In comparison with segmental resection, superficial resection has the benefits of technical simplicity, shorter operative times, lower complication rates, shorter hospitalization times, and better functional results in terms of continence and constipation ${ }^{(37)}$. The main disadvantage of the technique, as reported in a recent systematic revision and meta-analysis, is an increased recurrence rate in comparison with segmental resection (chance rate [OR] 5.53; $P=0.001)$ and with discoid resection (OR 3.83, $P=0.01)^{(45)}$.

\section{Discoid resection}

The discoid resection is the technique in which a full thickness resection is performed, restricted to the anterior rectal wall, followed by a sutured closure of the defect created. In cases of unifocal, deep and smaller than $3 \mathrm{~cm}$ lesions, discoid resection is considered the first option by many specialists ${ }^{(46,47)}$.

First described for treating deep endometriosis over 25 years $\mathrm{ago}^{(48)}$, variations of the technique may or not involve the use of mechanical staplers. When staplers are not used, resection of the full thickness of the rectal wall is performed, including the lesion; the defect created on the wall is then closed by sutures in one or two layers.

One option for the disc resection is the technique described by Gordon in 2001, which uses a circular stapler to repair the defect created by the excision of the lesion ${ }^{(49)}$. With the person under anesthesia, in the Lloyd-Davies position, and with a urinary catheter in place, the nodule resection is performed, creating a defect on the anterior rectal wall. Two stiches are applied at the extremities of the defect for better handling of the segment. The circular staple is then inserted through the anus and the area of the rectum that contains the defect is placed between the stapler's anvil and cartridge. Once the stapler is fired, the defect is repaired and a resection of the perilesional tissue takes place.

A variation of the procedure uses the circular stapler to simultaneously resect and repair the defect. In this technique, a transfixing stich is applied in the central of the lesion, after its dissection. When the lesion is large, a partial or total resection is recommended, followed by repair of the extremities with a transfixing stich, so that the remaining tissue or defect will be fully included in the treated region. The circular stapler is introduced through the rectum. The nodule is inserted in the stapler's chamber, between the anvil and the cartridge, using the repair stich previously applied to facilitate the positioning. The surgeon handling the stapler must anteriorize the device before completing closure. That way, when the device is fired, the nodule will be resect and the defect on the wall corrected by the stapling line, as illustrated in FIGURE 6.

We have routinely preformed endoscopic evaluation after the stapling, in order not only to verify the integrity of the anastomosis, but also to identify and endoscopically treat any bleeding.

The prospective data analysis of patients who underwent discoid resection in two endometriosis reference centers revealed good short-term results and low complication rates. According to the authors, the average size of the lesions was $30 \mathrm{~mm}(7 \text { to } 70 \mathrm{~mm})^{(50)}$. Despite the possibility, after a disc resection, of the margins being compromised in up to $40 \%$ of cases $^{(51)}$, there are few prospective and controlled studies comparing the technique with segmental resection in regard to late postoperative period, quality of life, 


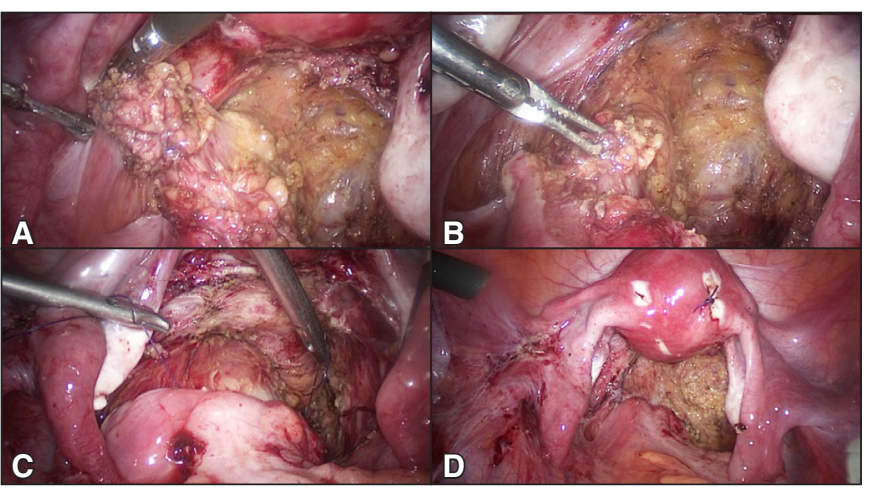

FIGURE 6. Discoid resection technique, with stapler. A) Dissection of the nodule. B) Partial resection of the nodule. C) Positioning of the nodule in the stapler by using the suture. D) Aspect after stapling.

and persistent remission ${ }^{(27,52)}$. Retrospective series and control case studies report recurrence rates between $1.8 \%$ and $10.4 \%$ for patients who underwent discoid resection ${ }^{(30,31,53)}$.

A further possibility in patients with more extensive lesions is the technique of double-transanal circular stapling ${ }^{(54)}$. Initially, the circular stapling technique described above is performed. After the first firing with a $33 \mathrm{~mm}$ stapler, a second firing is performed, with a $29 \mathrm{~mm}$ stapler. The aim of the second firing would be to remove residual tissue. Oliveira et al. performed double stapling in 11 out of 120 patients who underwent surgery for rectal endometriosis, with low complication rates, and consider the technique as an option to segmental resection in patients with unifocal lesions measuring between 2 and $4 \mathrm{~cm}^{(55)}$. In our view, since this technique resects a larger area of the anterior rectal wall, it might distort the organ's axis and lead to symptoms such as tenesmus and a sensation of incomplete evacuation, and we find it essential to wait for study results that would support is application from an anatomical and physiological perspective.

Roman et al. described a modification of the discoid resection procedure, called "Rouen technique." This procedure, which also allows for treating lesions bigger than $3 \mathrm{~cm}$, begins with the superficial resection of the nodule, followed by ablation with PlasmaJet ${ }^{\circledR}$, via laparoscopy. This technique is based on the properties of argon plasma, which presents less lateral heat dissipation, making the resection in contact with the rectal wall safer. Next, stiches are applied to the lesion through the anus, for traction of the target area, and a stapled trans-anal rectal resection is performed using Contour Transtar ${ }^{\mathbb{B}(56)}$

\section{Segmental resection}

Segmental resection is generally indicated in cases of unifocal lesions greater than $3 \mathrm{~cm}$ in diameter, two or more infiltrative lesions, or a unifocal lesion infiltrating more than $50 \%$ of the intestinal wall ${ }^{(38,57)}$

Segmental resection for the treatment of endometriosis is often not as extensive, and lymph node draining is not a concern when comparing to oncological resections; therefore, there is rarely the need to mobilize the splenic flexure. Nezhat et al. described for the first time, in 1992, the use of the technique for treating deep endometriosis with intestinal and rectovaginal septum involvement ${ }^{(58)}$.

Bowel preparation for colorectal surgery is controversial. When performed it usually consists of an anterograde preparation, as well as antibiotic prophylaxis - given orally on the day before, and in- travenously both intraoperatively and postoperatively, for 24 hours. With the patient under anesthesia, in the Lloyd-Davies position, and with a urinary catheter in place, the uterine manipulator is inserted to facilitate the pelvic approach.

Positioning of the trocars is usually determined by the surgeon, usually with an $11 \mathrm{~mm}$ trocar in the umbilical scar, a $12 \mathrm{~mm}$ trocar in the right iliac fossa for the linear stapler, and two $5 \mathrm{~mm}$ trocars in the left iliac fossa and right flank.

The surgery begins by inspecting the abdominal cavity to identify the affected places and structures; it is important to remember that all segments of the digestive tract may be compromised. In addition to the pelvic organs, the appendix, the terminal ileum, the diaphragm, and the peritoneal surface must also be evaluated.

The next step is the mobilization of the sigmoid colon and identification and preservation of the ureters. The pararectal space is opened, medially to the uterosacral ligament and preserving the nerves and the inferior hypogastric plexus. In segmental resections in endometriosis patients, there is no need for a block resection and sometimes dissection of the rectum is performed through the lesion, leaving endometriotic tissue to be removed after the stapling. This way, the nodule is dissected, and the rectum is sectioned with a linear stapler, ensuring a distal margin of 1 to $2 \mathrm{~cm}^{(37)}$. Afterwards, the eventual residual lesions, which may involve pelvic structures, are dissected and removed.

After the section, the colon can be externalized by extending the incision of one of the trocars, or via a Pfannenstiel incision. The piece may also be removed vaginally, as described by Redwine et al., via an incision in the posterior cul-de-sac ${ }^{(59)}$. Mechanical anastomosis is performed via double laparoscopic stapling with a circular stapler. Air leak testing is routinely performed, either by insufflating the rectum with air or by intraoperative colonoscopy, in order to assess the quality of the suture. Drainage, whether closedsystem or via a Penrose drain, is optional. FIGURE 7 illustrates the surgical steps of the segmental resection.

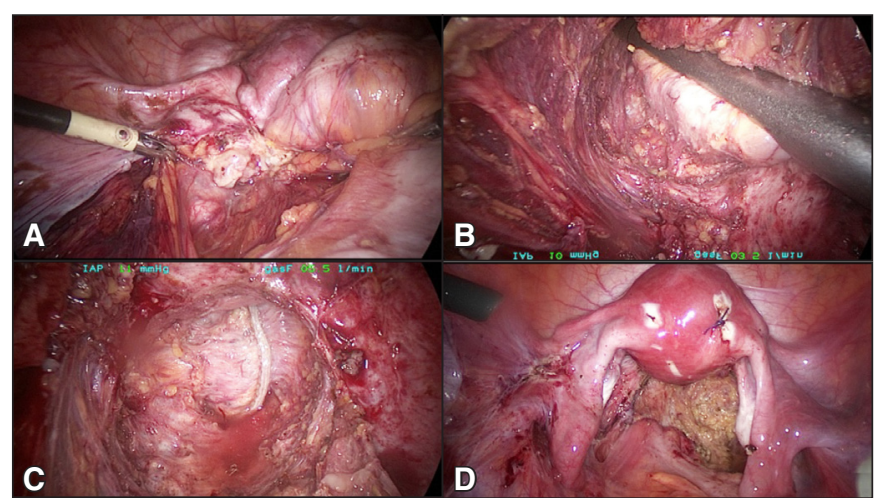

FIGURE 7. Segmental resection technique. A) Initial aspect. B) Linear stapling. C) Aspect after linear stapling. D) Final aspect after colorectal anastomosis.

Ruffo et al. reviewed 900 colorectal resections for deep endometriosis. The average follow-up period was of 54 months (1 to 120). They observed significant improvement in dyspareunia, constipation, pelvic pain $(P=0,0001)$ and diarrhea $(P=0.004)$. Nonsignificant improvement was observed in dysuria and anal bleeding $(P=0.452 \text { and } P=0.097 \text {, respectively })^{(60)}$. Approximately $40 \%$ of patients presented postoperative fecal thinning, with gradual improvement over the first year, in most cases ${ }^{(61)}$. 
A systematic review of 1889 colorectal resections and 961 rectal resections reported surgery times varying from 101 to 436 minutes. The hospitalization period varied between 4 and 14 days. Pain relief occurred in $71.4 \%$ to $93.6 \%$ of cases. Symptom recurrence, in the follow-up period of 2 to 5 years, varied between 4 and $54 \%$. Pain recurrence requiring reoperation varied between 0 and $34 \%$. Verified recurrence of endometriosis varied between 0 to $25 \%$. The cumulative rate of spontaneous pregnancy varied between $10 \%$ and $13 \%$. The cumulative pregnancy rate, including in-vitro fertilization, was of $18 \%$ to $100 \%{ }^{(9)}$.

The complete removal of endometriosis foci is more commonly associated with segmental resection, as compared to more conservative techniques ${ }^{(37)}$. A recent systematic review about histology-verified recurrence at least 12 months after intestinal endometriosis surgery covered 41 studies and selected four for the meta-analysis. According to the authors, the risk of recurrence was significantly lower in segmental or discoid resection when compared to superficial resection ${ }^{(45)}$. Histopathologic findings, such as the presence of satellite lesions, marginal positivity, and thickness of infiltration, seem to have no relation to recurrence rates or to impact on quality of life ${ }^{(62)}$.

Since segmental resection is associated to higher rates of complete resection and lower recurrence, there is doubt in the literature about the inferiority of intestinal or urinary functional results, compared to techniques that preserve the rectum ${ }^{(37,45)}$. Roman et al. conducted a randomized study to compare conservative techniques with colorectal resection in 60 patients who presented with lesions varying between 25 and $40 \mathrm{~mm}$, infiltrating the muscle layer, and with $50 \%$ of the rectal circumference compromised. The patients who underwent segmental resection presented increased risk of colorectal anastomotic stenosis, requiring dilation. However, conservative surgeries were not superior to the radical surgeries, in the population studied regarding digestive and urinary functions ${ }^{(52)}$. Data recently published by the same group, with a 5 -year follow-up period, also did not show long-term differences in functional results between conservative surgeries and segmental resection ${ }^{(27)}$. A fertility rate study was conducted with 55 of the 60 patients involved in that study. At the end of the follow-up period, which varied from 50 to 79 months, $81 \%$ of the patients were able to get pregnant. The gestation rate after surgical treatment was of $74 \%$ for patients considered unfertile, of which $53 \%$ were by natural conception ${ }^{(11)}$.

The treatment of multifocal intestinal lesions is subject for debate in the literature. Segmental resection is the treatment recommended by most of the groups and protocols ${ }^{(38,57)}$. However, nodules that present in the rectum close to the anal verge may lead to functional long-term sequelae in patients who underwent the radical surgery. One option in these cases is to treat the distal lesion by discoid resection, in order to avoid a low colorectal anastomosis. In this scenario, it is important that the resection of the proximal lesion must be done before the discoid resection of the distal lesion, in order to minimize the consequences of manipulating the discoid resection area and reduce the occurrence of fistulas. Additionally, the minimum distance of $5 \mathrm{~cm}$ must be observed between the stapling lines to preserve the vascularization of the segment between them. However, this technique is associated with a high incidence of rectovaginal fistulas ${ }^{(33)}$.

\section{Robotic-assisted resection techniques}

Laparoscopic surgery is considered the gold standard in comparison to conventional laparotomy, due to its proven benefits, such as faster recovery, lower hospitalization period, better cosmetic results, and improved conception rates ${ }^{(17)}$. However, the minimally invasive method presents a series of practical limitations, such as reduced mobility, two-dimensional vision, instability and dependence on the assistant surgeon for the camera, and a narrow angle of work in the pelvis. Robotic surgery, in this context, is a promising option to overcome these hurdles ${ }^{(63)}$.

Soto et al. published a multi-center, prospective, and randomized study with 73 patients, comparing the laparoscopic and robotic-assisted approaches, and did not find a statistical difference between the techniques in regard to operative time, blood loss, conversion to laparotomy, or intra- or postoperative complications. Other studies point in the same direction, suggesting that the higher cost associated with the robotic procedure does not reflect into better surgical outcomes ${ }^{(19,20)}$.

On the opposite direction, there is a discussion about the impact of new robotic platforms and the advancing learning curve in regard to the cost/benefit in colorectal surgery ${ }^{(64)}$. Therefore, it is possible that technological development and cost reductions may lead to increased use of robotic-assisted methods in greater complexity procedures.

\section{COMPLICATIONS}

The main complications in the surgical treatment of intestinal endometriosis can be categorized into intraoperative, postoperative, and those related to the abdominal laparoscopic procedure.

Complications associated with video laparoscopy are generally rare and are related to establishing the pneumoperitoneum, in $2 \%$ of the cases, and to the inadvertent lesion of vessels and organs, or herniations arising from the passage of the trocars, in less than $1.5 \%$ of cases.

As in other colorectal surgeries, the incidence of colitis by Clostridium difficile has been documented ${ }^{(65)}$.

Potential intra and postoperative complications in intestinal endometriosis are well established and must be considered when choosing between the conservative and the radical surgical approach. Endometriosis is a benign disease that affects young, productive patients that have high expectations of a cosmetic result. Complication rates for the different techniques are hard to estimate, due to the different studies methodology, and to the reports, which mostly mention only immediate outcomes and do not describe late functional results. However, complications seem to be significantly more frequent in the more complex procedures, and with low anastomosis. Case series studies report immediate complications in $15 \%$ to $38 \%$ of segmental resection patients, $12 \%$ to $23 \%$ of discoid resection patients, and $3 \%$ to $6 \%$ of superficial excision patients ${ }^{(6-66)}$.

Renner et al. reported $15 \%$ minor complications, and 15.9\% major complications, including fistulas, peritonitis, and bleeding requiring transfusion, in 113 patients who underwent segmental resection for deep endometriosis. Transitory urinary dysfunction was described in $22 \%$ of the cases, and sexual alterations, such as lessened lubrication during intercourse, were reported in $36 \%$ of the operated patients ${ }^{(67)}$. The same authors published their results for 134 patients operated without intestinal resection and reported lower rates of minor (12.7\%) and major (3.7\%) complications. Among the minor complications, urinary and sexual alterations were also frequent in patients who underwent conservative surgery ${ }^{(68)}$.

More serious complications, such as urinary and intestinal fis- 
tulas, are rare. A French multi-centric study included 1,135 patients who underwent surgery for intestinal endometriosis in 2015 . The most common procedure was superficial resection $(48.1 \%)$, followed by segmental resection $(40.4 \%)$ and discoid resection $(7.3 \%)$. Among the most serious complications reported are anastomotic fistulas $(0.8 \%)$, pelvic abscesses $(3.4 \%)$, and rectovaginal fistulas, which were more frequent in segmental resections $(3.9 \%)$ when compared to discoid (3.6\%) and superficial resections $(1.3 \%)^{(34)}$. A systematic review published by De Cicco et al. reported that $11 \%$ of patients who underwent deep endometriosis surgery presented major complications, with anastomotic dehiscence, intestinal fistulas, and severe obstruction occurring in $1.9 \%, 1.8 \%$, and $2.7 \%$ of the patients, respectively. Among minor complications, transitory urinary and intestinal dysfunction were reported in $8.1 \%$ and $3.6 \%$ of the $\operatorname{cases}^{(9)}$.

Ruffo et al., from a cohort of 750 patients of segmental resection, reported incidences of anastomotic dehiscence $(3 \%)$, rectovaginal fistulas $(2 \%)$, ureteral lesions $(0.7 \%)$, and a high number of protective ileostomies (14\%). The incidence of unfavorable functional results, such as bowel urgency and incontinence, found in colorectal resections with low anastomosis, were significantly lower ${ }^{(60)}$. Patients submitted to segmental resection for rectal endometriosis have low reported incidence of low anterior resection syndrome (LARS) compared to surgery for low rectal cancer ${ }^{(10,33)}$. Advances in technology and in nerve-sparing dissection techniques aim to improve short and long-term functional results.

A study including 364 patients compared complication rates of segmental, discoid, and superficial resection, using the ClavienDindo classification ${ }^{(28,69)}$. More serious complications, such as fistulas and abscesses, classified as Clavien $3 \mathrm{~b}$, were reported in $11.8 \%$ of the patients, $2 / 3$ of which in the segmental resection group. The main criticism to the retrospective study is the lack of uniformity in extension and severity of the disease among the groups. The clinical presentation of endometriosis was more complex in cases submitted to segmental resection. The authors suggest that, when it is feasible, superficial resection is associated with lower complication rates ${ }^{(28)}$.

Segmental resection is a standardized technique for treating rectal endometriosis that is safe and results in lower residual disease; however, depending on the distance of the nodule in the rectal wall, it is the technique most associated with potentially serious complications and unfavorable intestinal and urinary results. Discoid resection, on the other hand, has a higher probability of residual disease and a smaller incidence of fistulas, but, as it doesn't require mesenteric dissection and ligation, it can present greater intraoperative and immediate postoperative bleeding. Bleeding can be controlled via a low insufflation colonoscopy and clipping or adrenaline injection on the staple line ${ }^{(70)}$. Superficial resection is associated with the lowest complication rates, both immediate and late, and with higher recurrence rates ${ }^{(31)}$.

Compared to superficial and discoid resections in a retrospective study, more extensive segmental resections had the worst performance rates in various quality of life and bowel function indices, which assessed the occurrence of postoperative constipation, incomplete evacuation, abdominal pain, and straining and pain during defecation ${ }^{(66)}$. However, the initial and long-term results of two prospective randomized studies carried out by the same group did not show segmental resection as inferior in regard to digestive and urinary outcomes when compared to conservative surgeries ${ }^{(27,52)}$. Despite the difficulty in analyzing the techniques for treating deep endometriosis separately, a recent systematic review and meta-analysis showed improved quality of life in patients who underwent surgical treatment ${ }^{(8)}$. TABLE 2 compares the results of different surgical techniques for treating rectal endometriosis, based on different variables.

\section{CONCLUSION}

Surgical treatment of pelvic endometriosis with rectal involvement represents a challenge for surgeons and gynecologists. Choosing which technique to use is still a matter for debate and depends on a perfect preoperative staging and a thorough knowledge of the therapeutic strategies. The complete laparoscopic eradication of the endometriotic tissue is associated with the best results. The decision between a more conservative or radical approach must be made by a multi-disciplinary team, and must be made for each patient, individually. The proposed surgery must take into account the patient's symptoms and expectations, as well as risks, potential complications, recurrence rates, and the surgeon's expertise. Although arguments exist that favor the conservative approach, randomized and controlled studies comparing the various treatment options must inform the decision about what is the best technique for each patient.

\section{Authors' contribution}

Popoutchi P designed the study, collected and analyzed data, drafted the manuscript, revised the article for important medical content and approved the final manuscript draft. Marques Junior OW collected and analyzed data, drafted the manuscript and approved the final manuscript draft. Averbach P designed the study, collected and analyzed data, drafted the manuscript, revised the article for important medical content and approved the final manuscript draft. Cardoso Filho CAM collected and analyzed data. Averbach $\mathrm{M}$ designed the study, collected and analyzed data, drafted the manuscript, revised the article for important medical content and approved the final manuscript draft.

\section{Orcid}

Pedro Popoutchi: 0000-0002-2731-278X.

Oswaldo Wiliam Marques Junior: 0000-0002-4589-2749.

Pedro Averbach: 0000-0003-4024-9436.

Celso Augusto Milani Cardoso Filho: 0000-0001-7738-4602.

Marcelo Averbach: 0000-0002-3491-5781. 
Popoutchi P, Marques Junior OW, Averbach P, Cardoso Filho CAM, Averbach M. Técnicas cirúrgicas para o tratamento da endometriose do reto: revisão sistemática de ensaios clínicos randomizados e estudos observacionais. Arq Gastroenterol. 2021;58(4):548-59.

RESUMO - Contexto - A endometriose é uma doença prevalente em mulheres em idade reprodutiva e estimada em até $50 \%$ daquelas com infertilidade. $\mathrm{O}$ acometimento intestinal é reportado em até um terço dos casos. A doença é relacionada a dor crônica e perda de qualidade de vida, implicando em custos emocionais, sociais e econômicos. O tratamento consiste em bloqueio hormonal e ressecção cirúrgica, com efeitos colaterais e eficácia variáveis. A abordagem cirúrgica da endometriose do reto, conservadora ou radical, é motivo de discussão no que tange a indicação e a melhor técnica a ser empregada. Objetivo - Resumir os dados da literatura sobre as indicações, resultados e complicações das técnicas cirúrgicas para o tratamento da endometriose do reto. Métodos - Esta revisão sistemática abrangente é uma seleção de estudos da literatura e sua discussão, realizada por equipe com experiência no tratamento cirúrgico da endometriose intestinal, sobre as indicações, resultados e complicações das técnicas conservadoras, ressecção superficial e discoide, e radical para o tratamento cirúrgico da endometriose do reto. Foi realizada uma estratégia de busca nas bases de dados PubMed, EMBASE, e CENTRAL até maio de 2021 para identificar ensaios clínicos randomizados e estudos observacionais que compararam pelo menos duas das três técnicas cirúrgicas de interesse (i.e., shaving, ressecção discóide, ressecção segmental). Resultados - Um ensaio clínico randomizado e nove séries de casos, com um total de 3.327 pacientes, preencheram os critérios de elegibilidade da revisão. A idade dos participantes variou de uma média de 30,0 a 37,9 anos. O seguimento médio variou de 1,2 a 42,76 meses. Referente à qualidade metodológica, no geral os estudos incluídos apresentaram baixo risco de viés na maioria dos domínios avaliados. O tratamento cirúrgico das pacientes com endometriose do reto está indicado para as pacientes com sintomas obstrutivos e naquelas com escores de dor acima de 7/10. As pacientes com doença além da camada muscular própria do reto, documentada por meio de ressonância magnética ou ultrassonografia pélvica transvaginal com preparo intestinal, são candidatas a ressecção discoide ou segmentar. A presença de doença multifocal, extensão maior de $3 \mathrm{~cm}$ e infiltração maior $50 \%$ da circunferência da alça favorecem a técnica radical. A altura da lesão em relação a borda anal, idade, sintomatologia e desejo reprodutivo são outros fatores que podem influenciar na escolha da técnica a ser empregada. O risco de complicações e resultados funcionais desfavoráveis parecem estar relacionados diretamente a complexidade do procedimento. Conclusão - A escolha da técnica cirúrgica, conservadora ou radical, realizada pela via laparoscópica, para o tratamento da endometriose do reto é motivo de discussão e depende não somente do estadiamento pré-operatório, mas também das expectativas da paciente, dos riscos e potenciais complicações, das taxas de recorrência e da expertise da equipe multidisciplinar.

Palavras-chave - Tratamento; reto; endometriose.

\section{REFERENCES}

1. Wolthuis AM, Meuleman C, Tomassetti C, D’Hooghe T, de Buck van Overstraeten A, D'Hoore A. Bowel endometriosis: colorectal surgeon's perspective in a multidisciplinary surgical team. World J Gastroenterol. 2014;20:15616-23.

2. Zondervan KT, Becker CM, Missmer SA. Endometriosis. N Engl J Med. 2020;382:1244-56.

3. Vercellini P, Crosignani PG, Somigliana E, Berlanda N, Barbara G, Fedele L. Medical treatment for rectovaginal endometriosis: what is the evidence? Hum Reprod. 2009;24:2504-14.

4. Vercellini P, Pietropaolo G, De Giorgi O, Pasin R, Chiodini A, Crosignani PG Treatment of symptomatic rectovaginal endometriosis with an estrogen-progestogen combination versus low-dose norethindrone acetate. Fertil Steril. 2005;84:1375-87.

5. Ferrero S, Camerini G, Ragni N, Venturini PL, Biscaldi E, Remorgida V. Norethisterone acetate in the treatment of colorectal endometriosis: a pilot study. Hum Reprod. 2010;25:94-100.

6. Vercellini P, Somigliana E, Consonni D, Frattaruolo MP, De Giorgi O, Fedele L. Surgical versus medical treatment for endometriosis-associated severe deep dyspareunia: I. Effect on pain during intercourse and patient satisfaction. Hum Reprod. 2012;27:3450-9.

7. Vercellini P, Buggio L, Berlanda N, Barbara G, Somigliana E, Bosari S. Estrogen-progestins and progestins for the management of endometriosis. Fertil Steril. 2016;106:1552-71.

8. Arcoverde FVL, Andres MP, Borrelli GM, Barbosa PA, Abrão MS, Kho RM. Surgery for Endometriosis Improves Major Domains of Quality of Life: A Systematic Review and Meta-Analysis. J Minim Invasive Gynecol. 2019;26:266-78.

9. De Cicco C, Corona R, Schonman R, Mailova K, Ussia A, Koninckx P. Bowel resection for deep endometriosis: a systematic review. BJOG. 2011;118:285-91.

10. Riiskjaer M, Greisen S, Glavind-Kristensen M, Kesmodel US, Forman A, Seyer-Hansen M. Pelvic Organ Function Before and After Laparoscopic Bowel Resection for Rectosigmoid Endometriosis: A Prospective, Observational Study. BJOG. 2016;123:1360-7.

11. Roman H, Chanavaz-Lacheray I, Ballester M, Bendifallah S, Touleimat S, Tuech JJ, et al. High Postoperative Fertility Rate Following Surgical Management of Colorectal Endometriosis. Hum Reprod. 2018;33:1669-76.
12. Bazot M, Lafont C, Rouzier R, Roseau G, Thomassin-Naggara I, Daraï E. Diagnostic accuracy of physical examination, transvaginal sonography, rectal endoscopic sonography, and magnetic resonance imaging to diagnose deep infiltrating endometriosis. Fertil Steril. 2009;92:1825-33.

13. Guerriero S, Ajossa S, Orozco R, Perniciano M, Jurado M, Melis GB, Alcazar JL. Accuracy of transvaginal ultrasound for diagnosis of deep endometriosis in the rectosigmoid: systematic review and meta-analysis. Ultrasound Obstet Gynecol. 2016;47:281-9.

14. Roman H, Vassilieff M, Gourcerol G, Savoye G, Leroi AM, Marpeau L, et al. Surgical management of deep infiltrating endometriosis of the rectum: pleading for a symptom-guided approach. Hum Reprod. 2011;26:274-81.

15. Abrão MS, Andres MP, Barbosa RN, Bassi MA, Kho RM. Optimizing Perioperative Outcomes with Selective Bowel Resection Following an Algorithm Based on Preoperative Imaging for Bowel Endometriosis. J Minim Invasive Gynecol. 2020;27:883-91. doi: 10.1016/j.jmig.2019.06.010.

16. Dunselman GA, Vermeulen N, Becker C, Calhaz-Jorge C, D'Hooghe T, Bie B, et al. ESHRE guideline: management of women with endometriosis. Hum Reprod. 2014;29:400-12.

17. Touboul C, Ballester M, Dubernard G, Zilberman S, Thomin A, Dara1 E. Long-term symptoms, quality of life, and fertility after colorectal resection for endometriosis: extended analysis of a randomized controlled trial comparing laparoscopically assisted to open surgery. Surg Endosc. 2015;29:1879-87.

18. Averbach M, Popoutchi P, Marques OW Jr, Abdalla RZ, Podgaec S, Abrão MS. Robotic rectosigmoidectomy - pioneer case report in Brazil. Current scene in colorectal robotic surgery. Arq Gastroenterol. 2010;47:116-8.

19. Berlanda N, Frattaruolo MP, Aimi G, Farella M, Barbara G, Buggio L, Vercellini P. 'Money for nothing'. The role of robotic-assisted laparoscopy for the treatment of endometriosis. Reprod Biomed Online. 2017;35:435-44.

20. Soto E, Luu TH, Liu X, Magrina JF, Wasson MN, Einarsson JI, et al. Laparoscopy vs. Robotic Surgery for Endometriosis (LAROSE): a multicenter, randomized, controlled trial. Fertil Steril. 2017;107:996-1002.

21. Higgins JPT, Green S, eds. Cochrane handbook for systematic reviews of interventions version 5.1.0 [updated March 2011: The Cochrane Collaboration, 2011. [Internet]. Available from: http://handbook.cochrane.org/. 
22. Moher D, Liberati A, Tetzlaff J, Altman DG. Preferred reporting items for systematic reviews and meta-analyses: The PRISMA statement. BMJ. 2009;339:b2535.

23. Guyatt GH, Busse JW. Modification of Cochrane Tool to assess risk of bias in randomized trials. [Internet]. Available from: http://distillercer.com/resources/.

24. Guyatt GH, Oxman AD, Vist GE, Kunz R, Falck-Ytter Y, Alonso-Coello P, et al. GRADE Working Group. GRADE: an emerging consensus on rating quality of evidence and strength of recommendations. BMJ. 2008;336:924-6.

25. Guyatt GH, Busse JW. Modification of Ottawa-Newcastle to assess risk of bias in nonrandomized trials. [Internet]. Available from: http://distillercer.com/resources/.

26. Gagnier JJ, Kienle G, Altman DG, Moher D, Sox H, Riley D, CARE Group. The CARE guidelines: consensus-based clinical case report guideline development. J Clin Epidemiol. 2014;67:46-51.

27. Roman H, Tuech JJ, Huet E, Bridoux V, Khalil H, Hennetier C, et al. Excision Versus Colorectal Resection in Deep Endometriosis Infiltrating the Rectum: 5-year Follow-Up of Patients Enrolled in a Randomized Controlled Trial. Hum Reprod. 2019;34:2362-71.

28. Abo C, Moatassim S, Marty N, Saint Ghislain M, Huet E, Bridoux V, et al Postoperative Complications After Bowel Endometriosis Surgery by Shaving, Disc Excision, or Segmental Resection: A Three-Arm Comparative Analysis of 364 Consecutive Cases. Fertil Steril. 2018;109:172-8.

29. Ballester M, Roman H, Mathieu E, Touleimat S, Belghiti J, Daraï E. Prior colorectal surgery for endometriosis-associated infertility improves ICSI-IVF outcomes: results from two expert centres. Eur J Obstet Gynecol Reprod Bio. 2016;209:95-9.

30. Fanfani F, Fagotti A, Gagliardi ML, Ruffo G, Ceccaroni M, Scambia G, et al Discoid or segmental rectosigmoid resection for deep infiltrating endometriosis: a case-control study. Fertil Steril. 2010;94:444-9.

31. Hernández Gutiérrez A, Spagnolo E, Zapardiel I, Zapardiel I, Seivane RGA, Carrasco AL, et al. Post-operative complications and recurrence rate after treatment of bowel endometriosis: Comparison of three techniques. Eur J Obstet Gynecol Reprod Biol X. 2019;4:100083.

32. Hudelist G, Aas-Eng MK, Birsan T, Berger F, Sevelda U, Kirchner L, et al. Pain and fertility outcomes of nerve-sparing, full-thickness disk or segmental bowel resection for deep infiltrating endometriosis-A prospective cohort study. Acta Obstet Gynecol Scand. 2018;97:1438-46.

33. Millochau JC, Stochino-Loi E, Darwish B, Abo C, Coget J, Chati R, et al. Multiple Nodule Removal by Disc Excision and Segmental Resection in Multifocal Colorectal Endometriosis. J Minim Invasive Gynecol. 2018;25:139-46.

34. Roman H. A National Snapshot of the Surgical Management of Deep Infiltrating Endometriosis of the Rectum and Colon in France in 2015: A Multicenter Series of 1135 Cases. J Gynecol Obstet Hum Reprod. 2017;46:159-65.

35. Roman H, Bridoux V, Merlot B, Resch B, Chati R, Coget J, et al. Risk of bowel fistula following surgical management of deep endometriosis of the rectosigmoid: a series of 1102 cases. Hum Reprod. 2020;35:1601-11.

36. Reich H, McGlynn F, Salvat J. Laparoscopic treatment of cul-de-sac obliteration secondary to retrocervical deep fibrotic endometriosis. J Reprod Med. 1991;36:516-22.

37. Donnez O, Roman H. Choosing the right surgical technique for deep endometriosis: shaving, disc excision, or bowel resection? Fertil Steril. 2017;108:931-42.

38. Desplats V, Vitte RL, du Cheyron J, Roseau G, Fauconnier A, Moryoussef F. Preoperative rectosigmoid endoscopic ultrasonography predicts the need for bowel resection in endometriosis. World J Gastroenterol. 2019;25:696-706.

39. Nisolle M, Brichant G, Tebache L. Choosing the Right Technique for Deep Endometriosis. Best Pract Res Clin Obstet Gynaecol. 2019;59:56-65.

40. Fatehchehr S, Macik P, Sinervo K. CO2 Laser Shaving Technique for Resection of Rectosigmoid Endometriosis. J Minim Invasive Gynecol. 2015;22:S138.

41. Donnez J, Squifflet J. Laparoscopic excision of deep endometriosis. Obstet Gynecol Clin North Am. 2004;31:567-ix.

42. Donnez J, Squifflet J. Complications, pregnancy and recurrence in a prospective series of 500 patients operated on by the shaving technique for deep rectovaginal endometriotic nodules. Hum Reprod. 2010;25:1949-58.

43. Roman H, Moatassim-Drissa S, Marty N, Milles M, Vallée A, Desnyder E, et al Rectal shaving for deep endometriosis infiltrating the rectum: a 5-year continuous retrospective series. Fertil Steril. 2016;106:1438-45.

44. Roman H, Milles M, Vassilieff M, Resch B, Tuech JJ, Huet E, et al. Long-term functional outcomes following colorectal resection versus shaving for rectal endometriosis. Am J Obstet Gynecol. 2016;215:762.

45. Bendifallah S, Vesale E, Daraï E, Thomassin-Naggara I, Bazot M, Tuech JJ, et al. Recurrence after Surgery for Colorectal Endometriosis: A Systematic Review and Meta-analysis. J Minim Invasive Gynecol. 2020;27:441-51.

46. de Almeida A, Fernandes LF, Averbach M, Abrão MS. Disc resection is the first option in the management of rectal endometriosis for unifocal lesions with less than 3 centimeters of longitudinal diameter. Surg Technol Int. 2014;24:243-8.

47. Jayot A, Bendifallah S, Abo C, Arfi A, Owen C, Darai E. Feasibility, Complications, and Recurrence After Discoid Resection for Colorectal Endometriosis: A Series of 93 Cases. J Minim Invasive Gynecol. 2020;27:212-9.
48. Nezhat C, Nezhat F, Pennington E, Nezhat CH, Ambroze W. Laparoscopic disk excision and primary repair of the anterior rectal wall for the treatment of full-thickness bowel endometriosis. Surg Endosc. 1994;8:682-5.

49. Gordon SJ, Maher PJ, Woods R. Use of the CEEA stapler to avoid ultra-low segmental resection of a full-thickness rectal endometriotic nodule. J Am Assoc Gynecol Laparosc. 2001;8:312-6.

50. Abo C, Bendifallah S, Jayot A, Timoh KN, Tuech J-J, Roman H, et al. Discoid Resection for Colorectal Endometriosis: Results From a Prospective Cohort From Two French Tertiary Referral Centres. Colorectal Dis. 2019;21:1312-20.

51. Roman H, Opris I, Resch B, Tuech JJ, Sabourin JC, Marpeau L. Histopathologic features of endometriotic rectal nodules and the implications for management by rectal nodule excision. Fertil Steril. 2009;92:1250-2.

52. Roman H, Bubenheim M, Huet E, Bridoux V, Zacharopoulou C, Daraï E, et al. Conservative Surgery Versus Colorectal Resection in Deep Endometriosis Infiltrating the Rectum: A Randomized Trial. Hum Reprod. 2018;33:47-57.

53. Roman H, Darwish B, Bridoux V, Chati R, Kermiche S, Coget J, et al. Functional outcomes after disc excision in deep endometriosis of the rectum using transanal staplers: a series of 111 consecutive patients. Fertil Steril. 2017;107:977-86.

54. Kondo W, Ribeiro R, Zomer MT, Hayashi R. Laparoscopic Double Discoid Resection With a Circular Stapler for Bowel Endometriosis. J Minim Invasive Gynecol. 2015;22:929-31.

55. Oliveira MA, Crispi CP, Oliveira FM, Junior PS, Raymundo TS, Pereira TD. Double Circular Stapler Technique for Bowel Resection in Rectosigmoid Endometriosis J Minim Invasive Gynecol. 2014;21:136-41.

56. Roman H, Tuech JJ. Laparoscopic and transanal excision of large lower- and mid-rectal deep endometriotic nodules: the Rouen technique. Fertil Steril. 2014;102:e7.

57. Kho RM, Andres MP, Borrelli GM, Neto JS, Zanluchi A, Abrão MS. Surgical treatment of different types of endometriosis: Comparison of major society guidelines and preferred clinical algorithms. Best Pract Res Clin Obstet Gynaecol. 2018;51:102-10.

58. Nezhat C, Nezhat F, Pennington E. Laparoscopic treatment of infiltrative rectosigmoid colon and rectovaginal septum endometriosis by the technique of videolaparoscopy and the CO2 laser. Br J Obstet Gynecol. 1992;99:664-7.

59. Redwine DB, Koning M, Sharpe DR. Laparoscopically assisted transvaginal segmental resection of the rectosigmoid colon for endometriosis. Fertil Steril. 1996;65:193-7.

60. Ruffo G, Sartori A, Crippa S, Partelli S, Barugola G, Manzoni A, et al. Laparoscopic rectal resection for severe endometriosis of the mid and low rectum: technique and operative results. Surg Endosc. 2012;26:1035-40.

61. Bassi MA, Andres MP, Bassi CM, Neto JS, Kho RM, Abrão MS. Postoperative Bowel Symptoms Improve over Time after Rectosigmoidectomy for Endometriosis. [published online ahead of print, 2019 Oct 24]. J Minim Invasive Gynecol. 2019;S1553-4650(19)31261-0.

62. Mabrouk M, Spagnolo E, Raimondo D, Malvi D, Catena F, Ferrini G, et al. Segmental bowel resection for colorectal endometriosis: is there a correlation between histological pattern and clinical outcomes? Hum Reprod. 2012;27:1314-9.

63. Gianardi D, Giannini A. Minimally invasive surgery for deep-infiltrating endometriosis and its impact on fertility: can robotic surgery play a role? J Robot Surg. 2019;13:789-90.

64. Palmeri M, Di Franco G, Furbetta N, Morelli L. Comment on: 'Money for nothing'. The role of robotic-assisted laparoscopy for the treatment of endometriosis. J Robot Surg. 2019;13:529-30.

65. Damle RN, Cherng NB, Flahive JM, Davids JS, Maykel JA, Sturrock PR, et al. Clostridium difficile infection after colorectal surgery: a rare but costly complication. J Gastrointest Surg. 2014;18:1804-11.

66. Roman H, Vassilieff M, Tuech JJ, Huet E, Savoye G, Marpeau L, et al. Postoperative digestive function after radical versus conservative surgical philosophy for deep endometriosis infiltrating the rectum. Fertil Steril. 2013;99:1695-704.

67. Renner SP, Kessler H, Topal N, Proske K, Adler W, Burghaus S, et al. Major and Minor Complications After Anterior Rectal Resection for Deeply Infiltrating Endometriosis. Arch Gynecol Obstet. 2017;295:1277-85.

68. Lermann J, Topal N, Adler W, Hildebrandt T, Renner SP, Beckmann MW, et al. Major and Minor Complications After Resection Without Bowel Resection for Deeply Infiltrating Endometriosis. Arch Gynecol Obstet. 2018;298:991-9.

69. Dindo D, Demartines N, Clavien PA. Classification of surgical complications: a new proposal with evaluation in a cohort of 6336 patients and results of a survey. Ann Surg. 2004;240:205-13.

70. Shamiyeh A, Szabo K, Ulf Wayand W, Zehetner J. Intraoperative endoscopy for the assessment of circular-stapled anastomosis in laparoscopic colon surgery. Surg Laparosc Endosc Percutan Tech. 2012;22:65-7. 